\title{
CHACHAPOYA MORTUARY BEHAVIOR: A CONSIDERATION OF METHOD AND MEANING
}

\author{
COMPORTAMIENTO MORTUORIO CHACHAPOYA: \\ CONSIDERACIONES METODOLÓGICAS E INTERPRETATIVAS
}

\author{
Kenneth C. Nystrom ${ }^{1}$, Jane E. Buikstra ${ }^{2}$, and Keith Muscutt ${ }^{3}$
}

\begin{abstract}
The Chachapoya region of northern Perú is characterized by a remarkable range of mortuary customs whose nature is incompletely defined and interpreted. The focus of this paper is to consider a single aspect of Chachapoya mortuary behavior: the presence/ absence and method of mummification. Complex, anthropogenic mummy bundles have been recovered from the Laguna de los Cóndores while less well documented and described "cadavers" and bodies have been illustrated from pre-Inca contexts, some contained within anthropomorphic sarcophagi and others located in burial chullpas and open-air sites. In this paper, we provide a general synthesis of Chachapoya mortuary behavior and then present a case study from the mortuary site of Laguna Huayabamba, a Late Intermediate site where mummified remains have been recovered. The relationship between mummified bodies and skeletal remains at this site is viewed as stages within a more unified ritual landscape, structured by continued kin-based access to specific mortuary contexts.
\end{abstract}

Key words: Chachapoya, mummification, Inca.

La región de los Chachapoya ubicada en el norte del Perú se caracteriza por una gran diversidad de tradiciones y estilos mortuorios. El propósito de este artículo se centra en un solo aspecto del comportamiento mortuorio Chachapoya: presencia/ausencia de métodos de momificación. Complejos fardos funerarios antropogénicos han sido recuperados en la Laguna de los Cóndores, mientras que contextos preincaicos no bien documentados de cuerpos y restos esqueletales contenidos en sarcófagos, chullpas y campamentos abiertos han sido descritos. En este estudio entregamos una síntesis general del comportamiento mortuorio Chachapoya, y luego se presenta el estudio de caso del sitio funerario, Intermedio Tardío, Laguna Huayabamba, donde se han recuperado restos humanos momificados. La relación entre los cuerpos momificados y los restos esqueletales, de este sitio, se interpreta como diferentes fases de un mismo contexto ritual, estructurado por lazos de parentesco para permitir un acceso continuo a contextos mortuorios específicos.

Palabras claves: Chachapoya, momificación, Inca.

The physical remains of the ancestors play a pivotal social function in Andean communities, in both prehistoric (Buikstra 1995; DeLeonardis and Lau 2004; Dillehay 1995; Salomon 1995) and contemporary societies (Allen 2002; Bastien 1995). There is a recurring theme that emphasizes dryness and hardness, both in terms of actual physical human remains and in reference to those items that are attributed human qualities such as statues, stones (Allen 2002:47), and seeds (Gose 1994). These physical characteristics reflect the journey and fate of the soul and the perceived state of society (van Gennep 1909). Modern ethnographic research demonstrates the basic incompatibility of Christian and indigenous Andean beliefs concerning the relationship between the body and soul: the latter not being bound by a body:soul dualism (Allen 2002). The state of the soul reflects, and is reflected in, the physical condition of the corporeal body. A sinful person reanimates a flesh-eating rotting corpse while properly attended dry bones results in khuyaqkuna, or caring protectors (Allen 2002:41). Among the inhabitants of Huaquirca (Antabama province, Apurímac), the dry hard seed, the ultimate source of food and the promise of the continuation of the agricultural cycle is the result of the soul being reduced by the heat of the afterlife. Further, it is the animating water of life expelled from the dead

1 Anthropology Department, Wooster Science Building 124, State University of New York at New Paltz, 1 Hawk Drive, New Paltz, NY 12561, USA. nystromk@newpaltz.edu

2 School of Human Evolution and Social Change, Arizona State University, Anthropology Bldg. Rm 233, Tempe, AZ 852872402, USA.buikstra@asu.edu

3 Division of Arts, University of California, Santa Cruz, 1156 High Street, Santa Cruz, CA 95064, USA. rtykot@ cas.usf.edu 
body in the heat of the afterlife that feeds the seed (Gose 1994:131). Thus, the creation of a hard, dry seed reflects the balance between the world of the living and the world of the dead and ensures the continuity of the regenerative agricultural cycle. The significance attributed to dry, hard human remains, be they bones or mummies, equates with the hardness of stones and seeds and represents an altered state of animation, or as Allen (2002:47) calls it, "life crystallized". That this theme extends back in time is supported by colonial period documents, which attest to the significance attributed to the corporeal body of the ancestor and its foundational role in group social organization and production (Salomon 1995).

Social reproduction (Salomon 1995), fertility, including such aspects as agricultural production and regenerative cycles (Bloch and Parry 1982; Bastien 1995; DeLeonardis and Lau 2004; Gose 1994; Sillar 1996), and group identity (Chesson 2001; Dillehay 1995; Joyce 2001; Meskell 2000) are all ultimately connected to the relationship between the living and the dead. Thus, the corporeal remains of the ancestors and the ritual and physical landscapes that constitute mortuary behavior were avenues through which group rights and responsibilities could be established and reinforced (Bloch and Parry 1982:6). Within many Andean groups, access to land within the ayllu was based upon kinship (Bastien 1978) and lineages were traced to actual or fictive progenitors (Salomon 1995:321). Thus, the manipulation of ancestors or the spaces they occupy were powerful means of establishing and signaling control over resources and production (Buikstra 1995).

As archaeologists, we are limited in our ability to reconstruct behavior as we are confined to the physical vestiges of that behavior. This is no less true when dealing with mortuary rituals associated with the post-mortem manipulation of the human body. Given the ritual and social importance of the condition of physical body within Andean groups, it is not surprising that anthropogenic mummification practices lend themselves to the reconstruction of ritual behavior, as there is physical evidence to observe and record. Truly, anthropogenic mummification is ritual behavior materialized. In those instances were spontaneous mummies are found within an organized mortuary context (ie., a cemetery as opposed to glacier), it is the material culture associated with the body that is considered to be ritual behavior materialized. Therefore, our recognition and description of body processing techniques may be unduly influencing the interpretation of behavior. This paper will explore how the interpretation of post-mortem body processing techniques can influence our understanding of mortuary behavior. Specifically, this paper deals with potential effects of Inca conquest on the ancestors and mortuary behavior in the Chachapoya ${ }^{1}$ region of northern Peru. It has been suggested that the Inca introduced an anthropogenic mummification procedure following conquest, yet this rests on several assumptions: (1) that Inca mummies are anthropogenic, (2) that mummification did not exist in Chachapoya prior to Inca arrival, and (3) that the observed variation in Chachapoya mortuary behavior between the Late Intermediate Period (AD 1,000-1,470) and Late Horizon (AD 1,470-1,532) represents distinct and disparate traditions. While this paper cannot answer the first statement, it will discuss the latter points based on the evidence from the Laguna Huayabamba, a Late Intermediate Period Chachapoya mortuary site. We suggest that what has been interpreted as evidence the introduction of an anthropogenic mummification process is actually the result of an extended (Brown 1981) mortuary tradition in which mummified ancestors gradually transform, through continued access and interaction on the part of the living, into skeletal remains.

\section{Mummification in the Andes}

In the South American Andes, archaeologists have benefited from a rare mix of environmental conditions conducive for soft tissue preservation and, as discussed above, a pervasive cultural emphasis on dry, hard human remains. These factors have provided us evidence of a deep history of mummification in the Andes, stretching from the beginnings of the Chinchorro tradition around 7,000 $\mathrm{BC}$ on the southern Peruvian and northern Chilean Pacific coast (Arriaza 1995a, 1995b; Aufderheide 2003) to Spanish Colonial descriptions of royal Inca mummies. Scientific examinations have attempted to reconstruct method of production (Allison et al. 1974; Bittmann and Munizaga 1976; Guillén 1992, 2005; Rivera 1995) and as much as possible, the culture-specific significance of mummification (Arriaza 1995a; Buikstra and Nystrom 2003; Rivera 1995). As in any archaeological endeavor, the reconstruction of mortuary behavior rests upon 
adequate sampling, both in terms of geographic and temporal coverage. In addition to these everpresent concerns inherent in all archaeological endeavors, the human body is also subjected to both intrinsic (e.g. autolytic enzymes) and extrinsic (e.g. insect activity) decompositional forces that influence preservation, and thus representation, in the archaeological record. Further, there are three methodological biases that can influence our interpretation of mortuary behavior.

The first bias is semantic. When dealing with mummified remains, a common occurrence in the Andes, the terms we use to categorize the remains may inadvertently influence our discussion of ideology and ritual. Mummies that were produced due to favorable environmental conditions have been labeled variously as "spontaneous" or "natural", both of which denote accidental or without human intervention. If we consider the body as, on the one hand, a repository of social memory and as a vehicle for the materialization of ideology, characterizing any post-mortem treatment as accidental has significant implications for the reconstruction of ritual behavior. We remove the significance of the body itself and rely exclusively upon the built environment where the individual was recovered (i.e., location, size, or style of mortuary architecture) or material culture (i.e., textiles and ceramics) that may be interred with the individual. The body becomes irrelevant and its preservation is the biological equivalent of winning the lottery. On the other hand, bodies that were subjected to any procedure that slowed decomposition are termed "anthropogenic", explicitly conveying intentionality on the part of the culture in question. A key problem is that the modern Western definition of intentionality may not accurately reflect the concept in any number of pre-historic non-Western contexts.

This leads to the second bias. The distinction between anthropogenic and spontaneous mummies rests on a methodological bias which can more readily detect human intervention in the decomposition process such as evisceration, excerebration, and excarnation. Clearly, these measures lend themselves to the identification of intentionality and we must use caution in speculating beyond the available data. While we know that a body tightly wrapped in textile decays slower than an unwrapped body (Aufderheide 2003), we cannot conclude with certainty that the culture in question realized the significance of this action. Additionally, the process of decomposition may obliterate all evidence of cultural intervention leading to the classification of such bodies as "indeterminant" or even "spontaneous". In reality, the boundary between anthropogenic and spontaneous mummies can be fuzzy.

Lastly, while being aware of the methodological distinction between mummification processes, we must also consider the dichotomy between mummification and skeletal remains. While these are visually distinct categories, the social significance of their production may be isomorphic. Both body treatments can be considered as secondary burial processes (Hertz 1960 [1907]). Secondary burial processes are designed to reduce the corpse to pure dry bones, with both the soul and society moving through a dangerous liminality phase as the dead flesh decomposes. Full separation of the deceased from the living world occurred only at the time of the second funeral, the time of final disposal for the dry bones. The mummification processes also hardens the corrupting flesh and therefore the presentation of the mummy at the end of the processing period was equivalent to deposition of the bundled secondary interment (Hertz 1960 [1907]:41-42).

As the ancestors and the treatment of the corpse are socially significant components of Andean communities, dichotomizing mortuary behavior based on our ability to discern or interpret intentionality, or relying upon gross visual differences, may lead to erroneous conclusions regarding the social context of the mortuary behavior. With this foundation, we can move to consider the evidence for the imperial manipulation of the built environment and the body in Chachapoya.

The people referred to ethnohistorically as the Chachapoya were conquered by the Inca ca. AD 1470. Similar to other regions incorporated into the empire (Bray 1992; Costin et al. 1989; Covey 2000; D'Altroy 2003; D'Altroy and Bishop 1990; Hastorf 1990; LeVine 1987; Murra 1982), Chachapoya sociopolitical infrastructure, economics, production, and demographics were altered. Within the past decade, several new Chachapoya mortuary sites have been described with evidence suggesting that the Inca also significantly influenced Chachapoya mortuary behavior. The most dramatic of these sites have been at the Laguna de los Cóndores (Guillén 1998; von Hagen 2002) and Los Pinchudos (Morales 2002; Morales et al. 2002). Components of the Laguna de los Cóndores and Los Pinchudos mortuary sites date to the Late Intermediate Period (AD 1,000- 
1,470) and Late Horizon (AD 1,470-1,532), and in particular remains from the former site have structured current interpretations of Chachapoya mortuary behavior and how it was influenced by Inca conquest.

Inca social organization was grounded in the same fundamental kin-based dual moiety structure as those groups they conquered (Bauer 1992:137139; Moseley 1992:49), including the Chachapoya (Espinoza 1967:233). Fundamentally, access and control of resources was based on lineage membership and the ideological foundation of Inca imperialism capitalized on these similarities. By claiming a common lineage with local ayllus the Inca could legitimately claim kin-based rights over resources. An even more powerful message involved the insinuation of new "ancestors" into, or the manipulation of, local ritual landscape (Guillén 1998).

While the diachronic perspective afforded by these two contexts is valuable, independent lines of evidence have not yet established clear divisions between Inca and pre-Inca contexts. Thus, we still lack a carefully controlled context that establishes a baseline for pre-Inca Chachapoya mortuary behavior. To establish this baseline, this paper focuses upon a mortuary component, Laguna Huayabamba, from Vira Vira, a Late Chachapoya period (ca. 1,100$1,470 \mathrm{AD}$ ) site that pre-dates the Inca incursion, thus describing the human remains recovered from the site and reconstructing Chachapoya mortuary behavior prior to Inca influence.

Reconstructing pre-Inca Chachapoya mortuary behavior is vital for our understanding Inca imperialism and local reaction to conquest. Increasingly it is recognized that it is not accurate to characterize Inca imperial control as existing along a continuum of direct to indirect control, albeit spatially and temporally variable (D'Altroy 2005). Relationships between the Inca and the "conquered" was dynamic and interactive, a sequence of evolving relationships that moved along multiple pathways. Recent investigations have begun to examine the articulation of imperial control strategies with local sociopolitical structures (Alconini 2004; Covey 2000; D'Altroy et al. 2000; Morris and Covey 2006; Wernke 2006) and to explore how local intermediate elites may have been actively engaged in the implementation and modification of the former. Still, the active role of the local elites, be it acquiescence or resistance, has not been a major focus in Late Horizon research, and we must be wary of implicitly characterizing the social relationship between imperial core and conquered periphery as unidirectional. The imperial introduction or imposition of new mortuary behaviors, specifically body processing techniques, at least implicitly, adheres to this prevailing Late Horizon Inca-centric paradigm.

\section{Chachapoya Mortuary Behavior: Previous Research}

This review of previous research is limited by the fact that many Chachapoya mortuary sites have been disturbed prior to receiving systematic archaeological attention. Further, more remote areas have yet to be surveyed and so this discussion is by necessity exploratory. At present, discussion of Chachapoya mortuary behavior is structured by two primary variables: type of mortuary architecture or context and body processing technique. Though a number of radiocarbon dates have been produced (Table 1), temporal control over these variables is not well established.

While the most prevalent forms of Chachapoya mortuary architecture include the anthropomorphic sarcophagi, which appear to dominant the northern part of the region, and burial chullpas which are more commonly encountered in the south (Figure 1), there is a wide range of formal variation. While the oldest radiocarbon dates from mortuary contexts are from a cave burial (Table 1: Cerro Achil) very little research has been conducted regarding their place within the ritual landscape of the Chachapoya. Further, we know relatively little about burial in subterranean chambers in houses (Narváez 1996a, 1996b; Schjellerup 1997) as well as interments located within larger city walls at Kuelap (Narváez 1996a, 1996b) and Huepon (Schjellerup 1997). Both forms of interment are contemporaneous with the chullpa burial tradition discussed below (Table 1).

Material from burial chullpas has been radiocarbon dated to as early as AD 1,000 (Table 1: Laguna Huayabamba). Though the chullpas vary in terms of plan (round, semicircular, rectangular, and square), they exhibit a number of construction similarities including the use of cleaved white limestone slabs mortared with mud and the formation of external geometric designs (Schjellerup 1997). Based upon radiocarbon dates, the chullpa tradition continues during the period of Inca conquest, the Early Colonial period (von Hagen 2002; ca. 1,532-1,570 AD) and perhaps as late as 1,657 AD (Table 1: Los Pinchudos). 
Table 1. Published radiocarbon dates from Chachapoya mortuary sites.

Dataciones radiocarbónicas publicadas de sitios mortuorios Chachapoya.

\begin{tabular}{|c|c|c|c|c|}
\hline Site Name & $\mathrm{Lab} \#$ & Sample material & $\begin{array}{l}\text { Uncalibrated } \\
\text { C-14 date }\end{array}$ & Reference \\
\hline \multirow[t]{31}{*}{ Condores } & T12818A & Cotton & $414 \pm 35$ & Urton 2001 \\
\hline & T12819A & Cotton & $403 \pm 35$ & Urton 2001 \\
\hline & $\mathrm{T} 12821 \mathrm{~A}$ & Cotton & $834 \pm 35$ & Urton 2001 \\
\hline & $\mathrm{T} 12822 \mathrm{~A}$ & Cotton textile & $379 \pm 34$ & Urton 2001 \\
\hline & VERA-1568 & Insect remain & $360 \pm 30$ & Wild et al. 2007 \\
\hline & VERA-2506 & Corn & $265 \pm 35$ & Wild et al. 2007 \\
\hline & VERA-1570 & Corn husks & $375 \pm 35$ & Wild et al. 2007 \\
\hline & VERA-1569 & Straw & $430 \pm 35$ & Wild et al. 2007 \\
\hline & VERA-2998 & Twigs & $315 \pm 35$ & Wild et al. 2007 \\
\hline & VERA-2990 & Textile fragments & $380 \pm 35$ & Wild et al. 2007 \\
\hline & VERA-2991 & Textile fragments & $380 \pm 40$ & Wild et al. 2007 \\
\hline & VERA-1567 & Textile & $350 \pm 30$ & Wild et al. 2007 \\
\hline & VERA-2994 & Textile fragments & $340 \pm 30$ & Wild et al. 2007 \\
\hline & VERA-2996 & Textile fragments & $360 \pm 35$ & Wild et al. 2007 \\
\hline & VERA-2508 & Textile & $290 \pm 30$ & Wild et al. 2007 \\
\hline & VERA-2997 & Exterior textile wrapping & $290 \pm 35$ & Wild et al. 2007 \\
\hline & VERA-2999 & Interior textile wrapping & $335 \pm 35$ & Wild et al. 2007 \\
\hline & VERA-3001 & Interior textile wrapping & $295 \pm 35$ & Wild et al. 2007 \\
\hline & VERA-3001B & Interior textile wrapping & $320 \pm 35$ & Wild et al. 2007 \\
\hline & VERA-3002 & Exterior textile wrapping & $285 \pm 40$ & Wild et al. 2007 \\
\hline & VERA-2993 & Human rib & $325 \pm 30$ & Wild et al. 2007 \\
\hline & VERA-2995 & Human rib & $370 \pm 35$ & Wild et al. 2007 \\
\hline & VERA-3003 & Human rib & $340 \pm 30$ & Wild et al. 2007 \\
\hline & VERA-3004 & Fragment with soft tissue & $435 \pm 30$ & Wild et al. 2007 \\
\hline & VERA-3000 & Human rib & $430 \pm 30$ & Wild et al. 2007 \\
\hline & VERA-1565 & Bone, Individuo 11 & $425 \pm 35$ & Wild et al. 2007 \\
\hline & VERA-1566 & Bone, Individuo 11 & $375 \pm 40$ & Wild et al. 2007 \\
\hline & VERA-2992 & Human rib & $355 \pm 35$ & Wild et al. 2007 \\
\hline & VERA-2507 & Bone & $515 \pm 30$ & Wild et al. 2007 \\
\hline & VERA-1571 & Gourd remains & $580 \pm 30$ & Wild et al. 2007 \\
\hline & VERA-2505 & Wood & $820 \pm 35$ & Wild et al. 2007 \\
\hline \multicolumn{5}{|l|}{ Laguna } \\
\hline \multirow[t]{2}{*}{ Huayabamba } & Beta-147871 & Plant material & $950 \pm 50$ & Fernandez-Dávila 2008 \\
\hline & Beta-147872 & Plant material & $120 \pm 40$ & Fernandez-Dávila 2008 \\
\hline \multirow[t]{2}{*}{ Los Pinchudos } & AA-3969 & Straw from mortar & $305 \pm 45$ & Church pers. comm. 2008 \\
\hline & Beta-28042 & Structural wood & $250 \pm 50$ & Church pers. comm. 2008 \\
\hline \multicolumn{5}{|c|}{ Other published radiocarbon dates* } \\
\hline Cerro Achil & & - & AD 910 & Schjellerup 1997 \\
\hline \multirow[t]{3}{*}{ Huepon } & - & & AD 1050 & Schjellerup 1997 \\
\hline & & & $100 \mathrm{BC}$ & Schellerup 1997 \\
\hline & & & AD 1045 & Schjellerup 1992 \\
\hline Runashayana & & Human bone & AD 1165 & Schjellerup 1997 \\
\hline Patron Samana & K-5096 & Human bone & AD 1435 & Schjellerup 1997 \\
\hline Carajía & & - & AD $1460 \pm 60$ & Kauffmann 2002 \\
\hline Salte si Puedes & $\mathrm{K}-4355$ & Human bone & AD 1490-1610 & Schjellerup 1997 \\
\hline
\end{tabular}

* These dates are published without uncalibrated BP dates or information regarding calibration curves. 


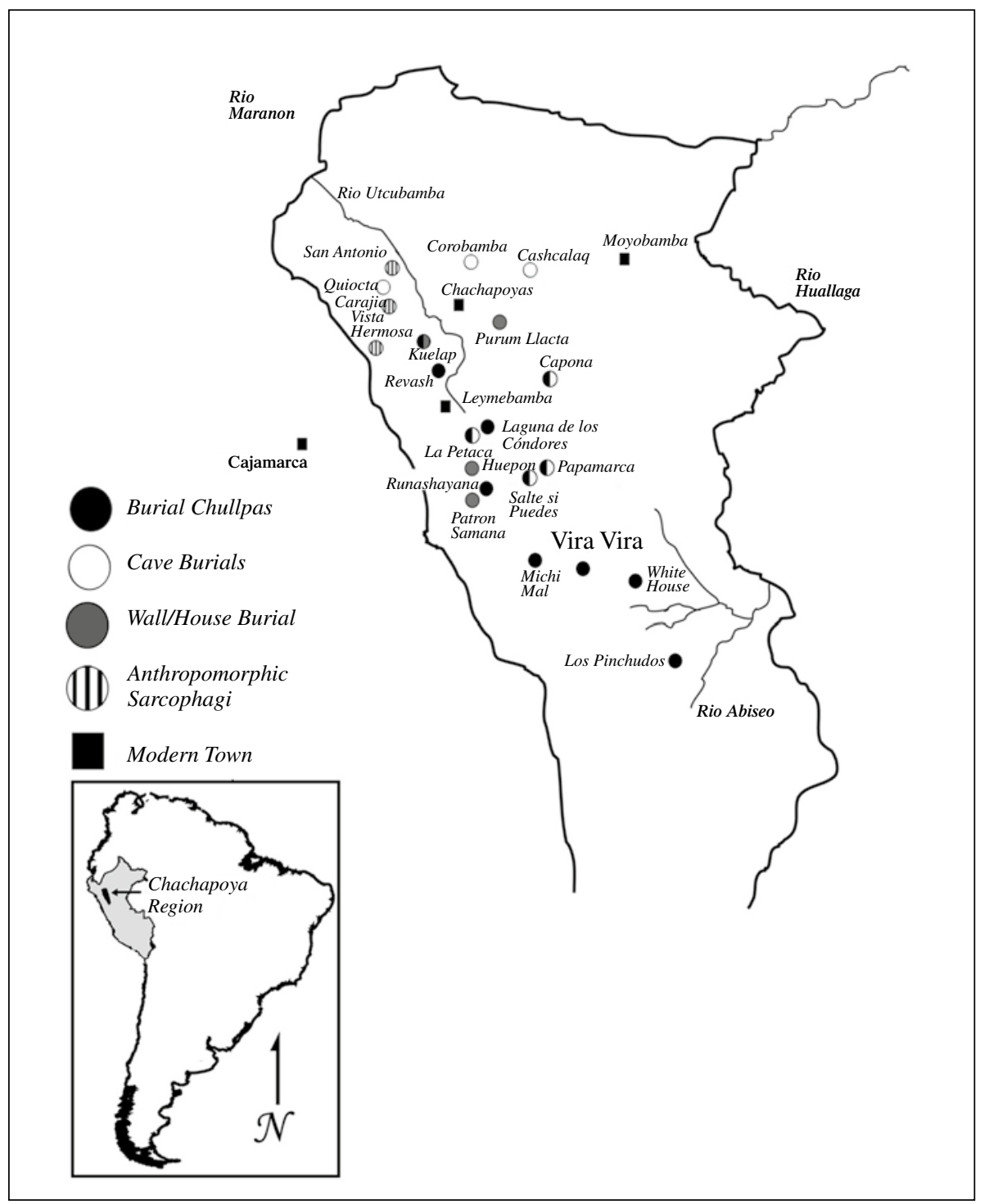

Figure 1. The Chachapoya region.

La región Chachapoya.

Continued use and access to these burial locations appears to be a common theme, therefore the actual construction of a chullpa may significantly pre-date many of its occupants. Multiple radiocarbon dates from different sources should be pursued in order to more firmly establish time depth.

Chachapoya anthropomorphic sarcophagi have attracted scholarly attention since the early 1930's, yet we know relatively little about them. While early explorers focused more attention on the encased human remains (Gil 1936; Langlois 1934, 1940), Kauffmann et al. (1989) did describe the variation exhibited by this type of mortuary architecture and grouped them into six classes based upon complexity (Kauffmann et al. 1989). The first class is the most elaborate, nearly $2.5 \mathrm{~m}$ tall with a sculpted and painted face, topped by a skull. The remaining classes decrease in size and decorative complexity, until the "pseudo sarcófago", which 0.6 to $0.8 \mathrm{~m}$ tall and are not decorated. While this classification scheme is useful in that it describes the range of behavior, temporal depth or diachronic change in construction technique is not addressed. Sarcophagi at the site of Carajía have been radiocarbon dated to AD 
1,460 \pm 60 years (Kauffmann 2002:544), which while overlapping the period of Inca conquest have never been attributed to be the result of Inca influence ${ }^{2}$. Further, it is not clear how the diversity exhibited in sarcophagi construction is related to social variables such as sociopolitical or economic status. It has been suggested that only elite individuals were accorded burial in the chullpas or anthropomorphic sarcophagi (Langlois 1934; Vreeland 1998:171). Presumably, this is based on an assumed correlation between the amount of energy expended in a particular mortuary activity and social status. There are scattered, Chachapoya-specific, references to this correlation, most vividly supported by a reference regarding the fate of the curaca Chuquimis of Cochabamba. After Chuquimis's unsuccessful treatment of an illness of Huayna Capac that resulted in the Inca's death, the bones of Chuquimis were taken from the cliffs "where they placed their most important dead, and he ordered them to be buried" (Espinoza 1967). Based upon the amount of Inca style ceramics found at Los Pinchudos, Morales and colleagues (2002) have suggested that the individuals interred at the site were members of a local elite ayllu politically aligned with the Inca. The correlation between socioeconomic status and mortuary treatment in Chachapoya has not been tested nor verified. Nor has it been established whether the apparent north/ south division of sarcophagi and chullpas represents intra-regional socio-political divisions or is merely an artifact of archaeological sampling.

Early $20^{\text {th }}$ century descriptions of Chachapoya body processing techniques are limited. Gil (1936) reported that the sarcophagi contained tightly flexed cadavers (1936:236) while Langlois $(1934,1940)$ describes sarcophagi containing mummies wrapped in cotton textile (1940a:198). At Kuelap, Langlois (1934:30) describes observing disarticulated crania ${ }^{3}$ and poses several scenarios, including that the remains were the war trophies of Chachapoya warriors or perhaps that the individuals died away from Kuelap and that some of the remains were lost in transit ${ }^{4}$ (Langlois 1934:30). More recently, Kauffmann et al. (1989) describe the remains in one of the largest classes of sarcophagi as a mummy wrapped in textiles, seated in flexed or extended position within an animal skin that covers the inferior half of the body ${ }^{5}$. Unfortunately, except for the single radiocarbon date associated with the sarcophagi at Carajía mentioned above, we do not know the temporal relationship between these different types of remains. Further, we do not know if the "cadavers" described by Kauffmann et al. (1989) were anthropogenic or spontaneous in origin.

In the last decade, human remains recovered from two sites have greatly expanded our knowledge of Chachapoya mortuary behavior. Remains from the Laguna de los Cóndores and Los Pinchudos have led to the dichotomization of regional mortuary behavior, contrasting secondarily interred skeletal material characteristic of pre-Inca Chachapoya mortuary behavior with the introduction of artificial mummification procedures by the Inca.

Like most sites in the region, the material at Los Pinchudos was disturbed by looters. While Kauffmann's (1997) report on the site contained a drawing of two mummy bundles in one of the chullpas, no mummies were recovered by Morales and colleagues during their more recent excavations (Morales et al. 2002). Morales et al. (2002) propose a four phase construction sequence which likely took place during the 60 year span of the Late Horizon. The first sample (AA-3969, straw from mortar from a wall of chullpa 5) produced two peaks; AD 1,495-1,675 at 84\% confidence and AD 1,739-1,799 at $11.4 \%$ confidence. Calibration of the second sample (Beta 28042, wood used in the construction of chullpa 1) produces many intercepts and as such is not particularly useful (Table 1, Figure 7) ${ }^{6}$. Bones from an estimated 186 individuals (Bracamonte 2002) were recovered from nearly all of the structures. In terms of mortuary behavior, Morales and colleagues (2002) suggest that the remains were the result of a secondary interment ritual.

In 1997, a team of archaeologists recovered a rich and well-preserved assemblage of archaeological material from the Laguna de los Cóndores. Though the site had been disturbed, studies of this collection have not only contributed to our understanding of the Chachapoya but have also enriched our understanding of Inca imperialism. Most pertinent to the current discussion, the team recovered human remains that have subsequently been separated into two distinct categories; secondarily interred skeletal remains and anthropogenic mummy bundles.

The remains of approximately 1000 skeletonized individuals (Guillén 2003), attributed to a Chachapoya ethnic group known as the Chilchos (Guillén 1998; von Hagen 2002) were recovered from two chullpas (von Hagen 2002). Many of 
the remains exhibit evidence of the application of red pigment (von Hagen 2002), suggesting that they were the focus of a secondary mortuary ritual. Undecorated bundles containing secondarily interred skeletal remains were also recovered in which there was no attempt to reconstruct a complete "individual" in anatomical position other than placing the skull at the superior end of the bundle (Guillén 2003). In an earlier publication, Guillén (2003) provided a date range for these skeletal bundles of AD 1100-1420. Wild et al. (2007) provides calibrated and uncalibrated data for three samples associated with these skeletal bundles (Table 1: VERA-2507, VERA-1571, and VERA-2505) ${ }^{7}$.

The mummy bundles recovered from La Laguna de los Cóndores are described as anthropogenic because there is evidence that the internal organs were removed via either the rectum or the vagina and that the skin may have been treated with some form of natural antiseptic (Guillén 1998:47). All ages seem to have been accorded treatment, including children, fetuses, and neonates, though they may not have been eviscerated (Guillén 2003). Again, in an earlier publication, Guillén (2003) provides an age range for the mummy bundles of AD 1,410-1,640. Wild et al. (2007) produced a number of calibrated radiocarbon age ranges (Table 1) from bone and textile associated with these mummy bundles ${ }^{8}$.

This series of radiocarbon dates led the researchers (Guillén 2003; Wild et al. 2007) to conclude that there was a change in how the body was prepared for burial following Inca conquest, from secondary interment of dry bones to the introduction of an anthropogenic mummification procedure. According to the researchers, following Inca conquest the skeletal remains of the Chachapoya were removed from their original enclosures and were replaced by the mummy bundles of foreign administrators, mitimae groups introduced into the region, as well as local lords and kin (Guillén 1998, 2005; von Hagen 2002).

The anecdotal evidence presented at the beginning of this section is not enough to counter this argument. However, human remains recovered from the Laguna Huayabamba, suggest that this proposed temporal relationship is not as straightforward as originally thought.

\section{Vira Vira and Laguna Huayabamba: Site Description}

The archaeological site of Vira Vira is in the Departmento San Martín, between the headwaters of the Ríos Huayabamba and Totora (Figure 1), set around the Laguna Huayabamba. The site consists of two components; (1) a residential sector with an estimated 200 structures on the south side of the lake and (2) a funerary component, henceforth referred to as Laguna Huayabamba. While archaeological investigations at the site are limited, there are some preliminary findings (Muscutt et al. 1994). There is a 3 to $4 \mathrm{~m}$ high perimeter wall that partially encloses the site and defines the western and northern boundaries. Whether this wall served a defensive purpose is unclear, for the eastern end of the site, which contains nearly $75 \%$ of the structures, is located outside of this presumed defensive feature (Lee 1994). The Edificio Principal is a $6 \mathrm{~m}$ high round structure that has a series of outward facing niches around its center (Lee 1994). The remaining structures on the peak form a U-shape. Twenty meters from the apex of the $U$ there is a natural spring that at one time may not have only served to irrigate the terraced landscape in-between the wings of the U, but may also have served an important ritual function (Sharon 1994). Though Vira Vira lies on the purported route of the conquering Inca, there were no indications of an Inca presence (Muscutt et al. 1994).

The tomb in which Muscutt and colleagues recovered the human remains was one of several on the cliff face (Briceño and Muscutt 2004). Approximately $5 \mathrm{~m}$ above the ground, the tomb was enclosed by a masonry stone wall and contained the both mummified and skeletonized remains. Radiocarbon analysis of plant material of anthropogenic origin associated with the mummy bundles (Beta 147873: 95\% confidence, AD 1,017-1,180 and Beta 147871; $95 \%$ confidence AD 1,028-1,219) place the material in the Late Chachapoya period, well before the ca. 1470 AD Inca conquest (Table 1). Additionally, a Middle Cajamarca B and Late Cajamarca (Cajamarca Semicursive) plate (Terada and Matsumoto 1985) was recovered from the site (Figure 2). While this tentatively supports a pre-Inca data from the site, it is possible that the plate was introduced in a later time period. 


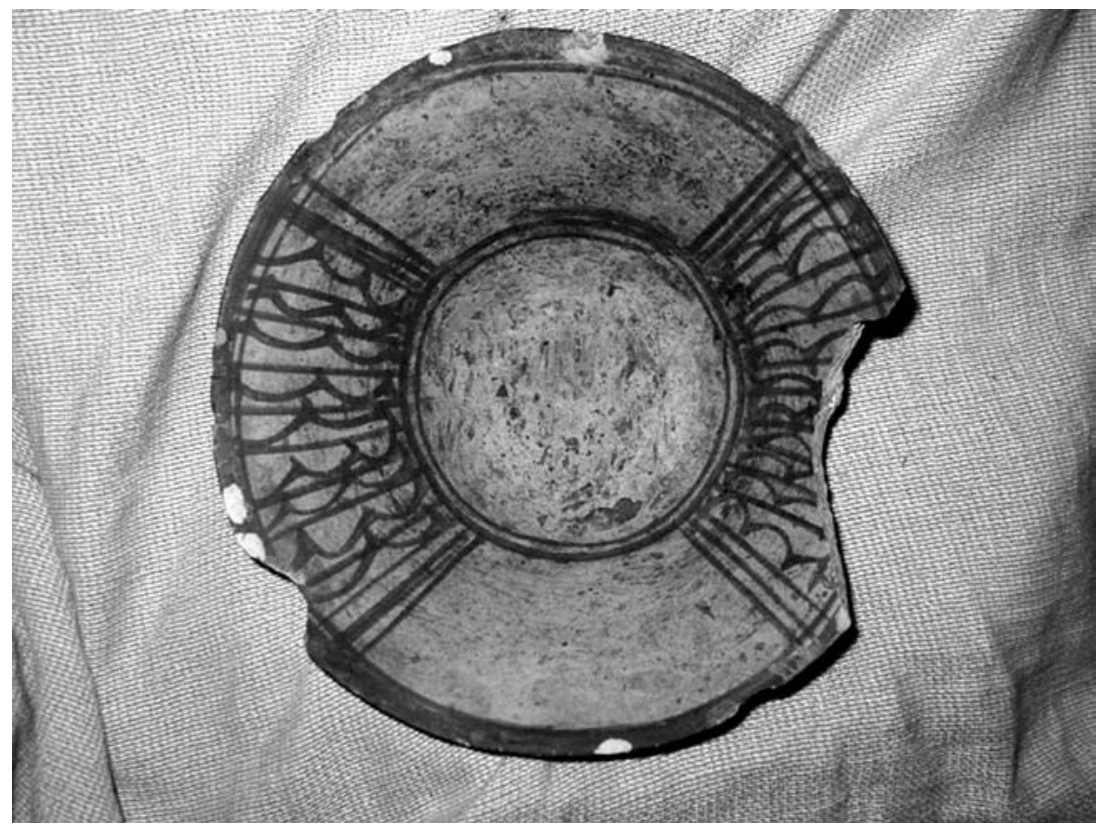

Figure 2. Cajamarca ceramic plate recovered from Laguna Huayabamba mortuary context.

Plato de cerámica Cajamarca recuperado en un contexto mortuorio de Laguna Huayabamba.

\section{Laguna Huayabamba: Mortuary Behavior}

Because our ability to reconstruct mortuary behavior is influenced by sampling and taphonomic considerations, a short discussion of the condition of the material is warranted.

Damage due to taphonomic processes varied considerably throughout the sample. A number of skeletal elements exhibited evidence of bleaching and exfoliation due to exposure to the environment. This contrasts with the amount of soft tissue evident on a number of the individuals. Additionally, the recovered textiles were strong and still retained vibrant colors. This range in preservation and taphonomic changes is due to original positioning of the elements within the cave. A number of skulls were recovered partially buried within the cave matrix where some showed green fungal growth which created small erosive cavities.

There are a total of 48 (Table 2), both skeletal and mummified, individuals in the Laguna Huayabamba sample. Age and sex estimates (Table 3) for those individuals were derived based upon observation of cranial morphology (Buikstra and Ubelaker 1994). Given the number of individuals that retained significant amounts of soft tissue or were wrapped as mummy bundles, there are a number of adults
Table 2. Age/Sex distribution for the Laguna Huayabamba collection $(\mathrm{n}=48)$. Distribución de sexo y edad de la colección de Laguna Huayabamba $(n=48)$.

\begin{tabular}{lcccccc}
\hline & $0-19$ & $20-34$ & $35-50$ & $50+$ years & "Adult" & Total \\
\hline Male & 0 & 5 & 5 & 2 & 2 & 14 \\
Female & 0 & 4 & 2 & 3 & 4 & 13 \\
Indet. & 13 & 1 & 0 & 0 & 7 & 21 \\
Total & 13 & 10 & 7 & 5 & 13 & 48 \\
\hline
\end{tabular}

Table 3. Age and Sex distribution for the Laguna Huayabamba collection, observable crania only $(\mathrm{n}=25)$. Distribución de sexo y edad de la colección de Laguna Huayabamba, a partir de la observación de los cráneos $(n=25)$.

0-19 20-34 35-50 50+ years "Adult" Total

\begin{tabular}{lcccccc}
\hline Male & 0 & 2 & 6 & 2 & 0 & 10 \\
Female & 0 & 2 & 1 & 3 & 0 & 6 \\
Indet. & 8 & 1 & 0 & 0 & 0 & 9 \\
Total & 8 & 5 & 7 & 5 & 0 & 25 \\
\hline
\end{tabular}


with indeterminate sex $(n=7)$. It was possible to estimate sex for 27 individuals (males, $n=14$; females, $n=13$ ). There were also a large number of subadult remains $(n=13)$. Two factors influence our ability to compare the demographic makeup of the skeletal and mummified material. First of all, as mentioned above, seven mummies were so intact that it was impossible to assign age or sex. Secondly, the sample is small, and as such we would only be able to compare frequencies without subsequent statistical support.

There are 17 individuals that are, or were at one time, wrapped in textiles. Seven mummies were still enveloped in textile wrappings, while an additional 10 retained textile or cord impressions on the skin. All of these individuals appear to have been in a tightly flexed position. Arm and leg positions ranged from the former being between the chest and legs to being placed outside and wrapped around the legs. Wrappings included vegetal fiber cords, light beige colored woven textiles with series of parallel dark stripes with dark orange borders, a light tan and dark brown woven textiles, raw cotton. Five of the individuals were wrapped in the same type of

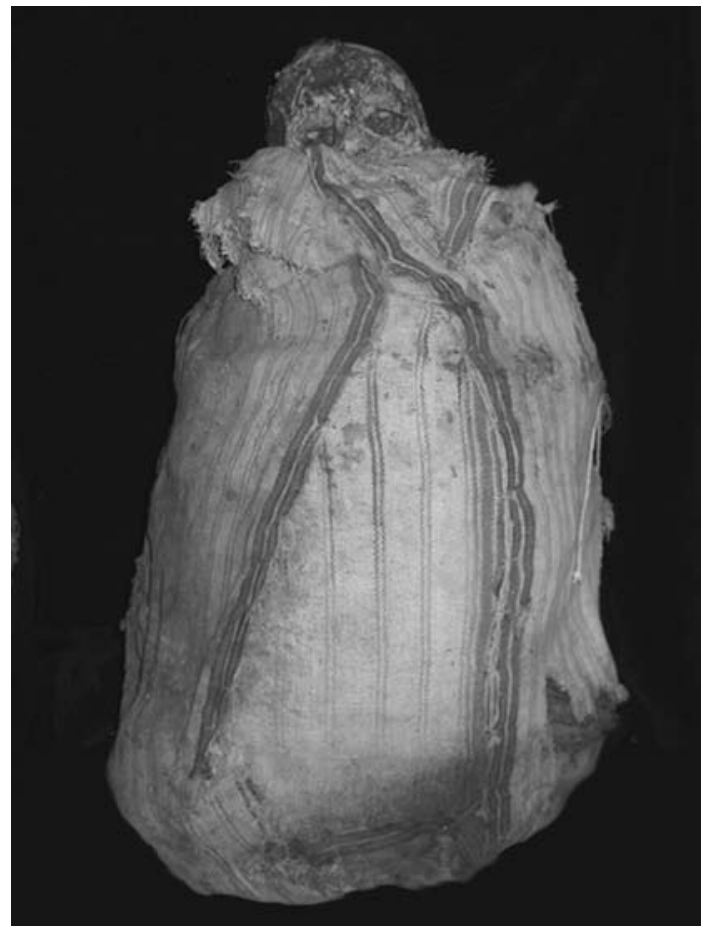

Figure 3. Example of the external wrappings on one of the intact Laguna Huayabamba mummies.

Ejemplo de envoltorio exterior de un fardo funerario intacto de Laguna Huayabamba. external woven textile (an example is provided in Figure 3), consisting of a light beige textile with a series of vertical parallel darker brown stripes with a dark orange border which could be some form of kin-based decoration. The most variable component seems to be the middle layers, which ranged from raw cotton, to a dark brown woven textile with stitched patterning, to a vegetal cord sack.

There are two noteworthy departures from the above mentioned anatomical positioning and textiles. Both involve the insertion of either the hands (Figure 4: Fardo 9) or arms and feet (Figure 4: Fardo 4) into what amounts to textile sleeves or gloves. In the first example, the hands were wrapped in textiles and then the fingers were individually stitched together through the intervening textile, in effect producing a mitten (Figure $4 b$ ). The second example seems to involve a similar process but with a significant difference. The hands, forearms, and possibly the arms, were wrapped in a dark brown woven textile, but the fingers were not stitched together through the material. Instead, this glove was then tied to a light brown hood that at one time
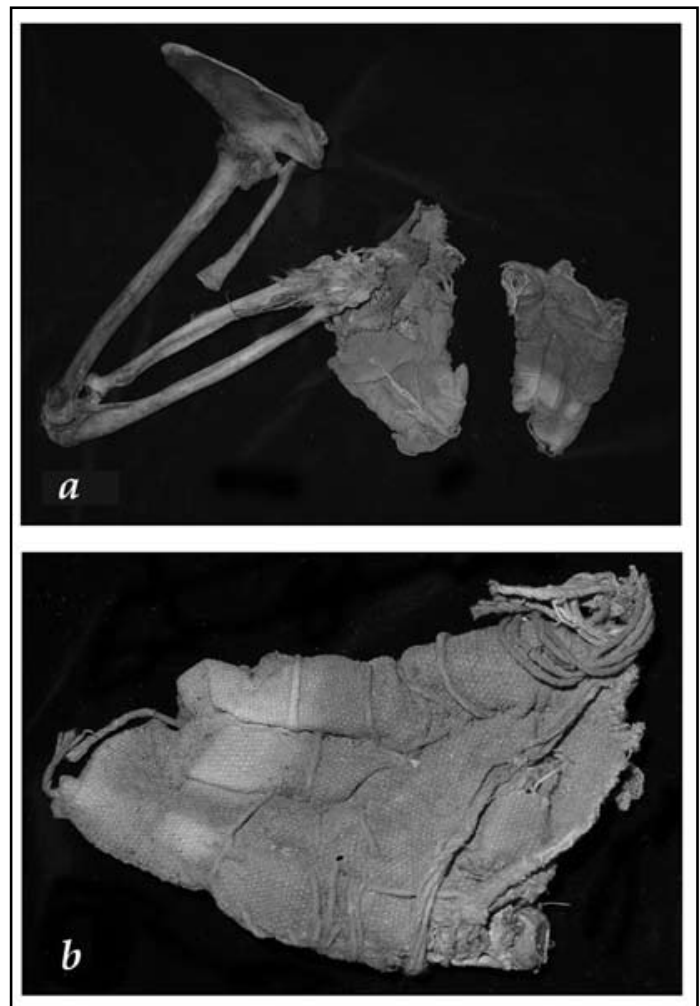

Figure 4. (a) Textile gloves from Fardo 9 with (b) close-up of glove. (a) Guantes tejidos pertenecientes al Fardo 9 (b) detalle del guante. 
appears to have completely covered the individual (Figure 5a). Though not as well preserved, the same type of dark brown woven textiles remain attached to the right foot (Figure 5b).

Given the condition of most mummy bundles, it is difficult to conclude with certainty if the individuals were eviscerated before they were wrapped in textiles. There was a single individual, however, that was clearly not eviscerated. Fardo 7 has a prolapsed rectum, which may be the result of the post-mortem buildup of intra-abdominal gases (Figure 6). The remaining mummy bundles either suffered too much taphonomic damage or were still completely enveloped in textiles for an accurate assessment of evisceration.
Children appear to have been placed at the funerary site with little or no postmortem processing (Figure 7). There are five newborn individuals that retain a significant portion of the skeleton, which is still in articulation due the presence of soft tissue. Indeed, one individual appears to retain vestiges of internal thoracic organs, the only such example of visible internal organs within the sample. There is no evidence for the presence of textiles in association with these juveniles, nor is there any suggestion that they were wrapped at any point. This conclusion is suggested by the lack of any textile markings on the skin of several of these juveniles. These same textile markings are clearly visible on a number of the adult individuals.

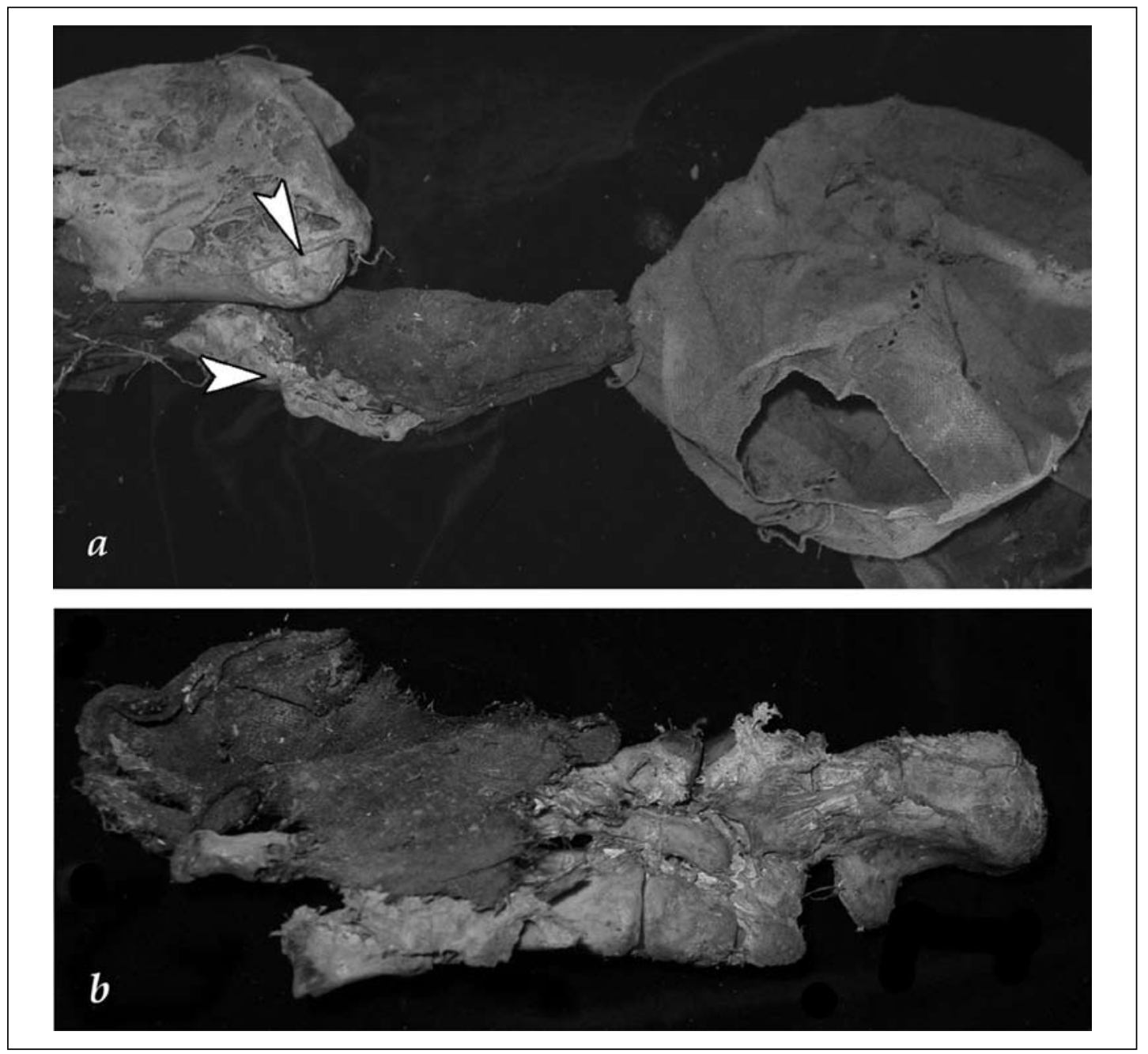

Figure 5. (a) Textile sleeves and hood (arrows are pointing towards head of the humerus and carpals) and (b) textile covering of right foot from Fardo 4.

(a) Mangas y capuchón del tejido (las flechas señalan la cabeza del húmero y carpianos) y (b) tejido cubriendo el pie derecho, Fardo 4. 


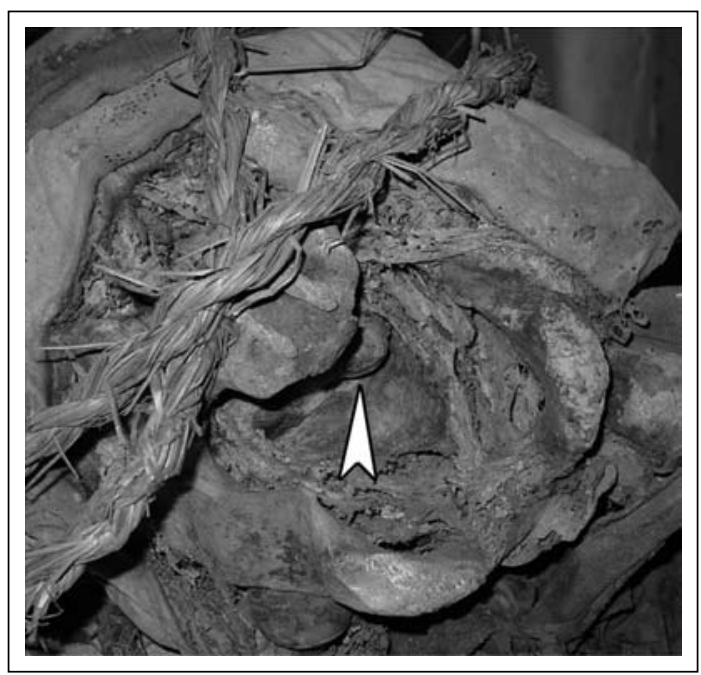

Figure 6. The arrow points towards a possible prolapsed rectum evident for one of the Laguna Huayabamba mummies.

Laflecha muestra un posible prolapso anal de uno de los cuerpos momificados de Laguna Huayabamba.

In addition to the mummy bundles described above, there were 10 crania that could not be positively associated with the remaining skeletal material. At present it is not possible to establish the temporal relationship between these remains and the mummy bundles and primary interments. Radiocarbon dates produced from the funerary component of the site were derived from vegetal material taken from the mummy bundles rather than from human tissue directly.

\section{Discussion and Conclusion}

The ancestors, providers of food and other resources and the repository of social memory, occupied a central position in the social and political landscapes of Andean communities. As such, mortuary rituals associated with the ancestors were a potent means through which individuals or groups could create symbolic capital for use in this sociopolitical landscape (Verdery 1999). While the observation of diachronic formal variation in mortuary behavior may be an indicator of social change (Aldenderfer 1993), investigators must remain aware of potential analytical biases. The categorization of mummification styles is inherently biased towards anthropogenic processes that can be detected with modern investigative tools or methods (e.g. chemical treatment of the skin, observation of ethmoid perforation via computed tomography). Therefore the separation into anthropogenic and spontaneous mummification processes, while a heuristically useful tool, may inadvertently color our insight into the social context surrounding the mummies themselves. Further, different forms of disposal (e.g. mummification versus secondary interment of dry bones) while visually and methodologically distinct, may not be so different in meaning.

Grounded in this perspective, this paper allows us to discuss the three assumptions stated at the beginning of this paper: (1) that Inca mummies were anthropogenic in origin, (2) that mummification did not exist in Chachapoya prior to Inca arrival, and (3) that the observed variation in Chachapoya mortuary behavior between the Late Intermediate Period (AD 1,000-1470) and Late Horizon (AD 1,470-1,532) represents distinct and disparate traditions.

We cannot unequivocally state that Inca mummies were anthropogenic given that no Inca mummies have survived to the present day for examination (Aufderheide 2003:124). True, many mummies that date to the Late Horizon have survived, but an example of a royal Inca mummy has yet to be found. Therefore it is impossible to classify them as either anthropogenic or spontaneous. Their current status as being anthropogenic is based primarily on the description of the early Spanish chroniclers, who were no doubt influenced by their knowledge of ancient Egyptian mummification. Arriaza (1995a) and Vreeland (1998) have expressed skepticism concerning the characterization of Inca mummification as being anthropogenic.

In order to address the second point and understand how Inca conquest influenced mortuary behavior it is vital that we reconstruct pre-conquest Chachapoya mortuary behavior. As should be evident from the preceding discussion, there is a wide range of observed mortuary behavior in the Chachapoya region and there are scattered reports of mummified remains. Unfortunately, two factors are limiting our ability to reconstruct Chachapoya mortuary behavior. First, for the most part these are anecdotal reports and are of limited value. Secondly, many of the sites that have been systematically investigated have been disturbed by looters. However, based predominantly on the human remains and radiocarbon dates (Wild et al. 2007) from the Laguna de los Cóndores, it has been suggested that normative Chachapoya mortuary behavior consisted of secondarily interred skeletal material while anthropogenic mummification was 

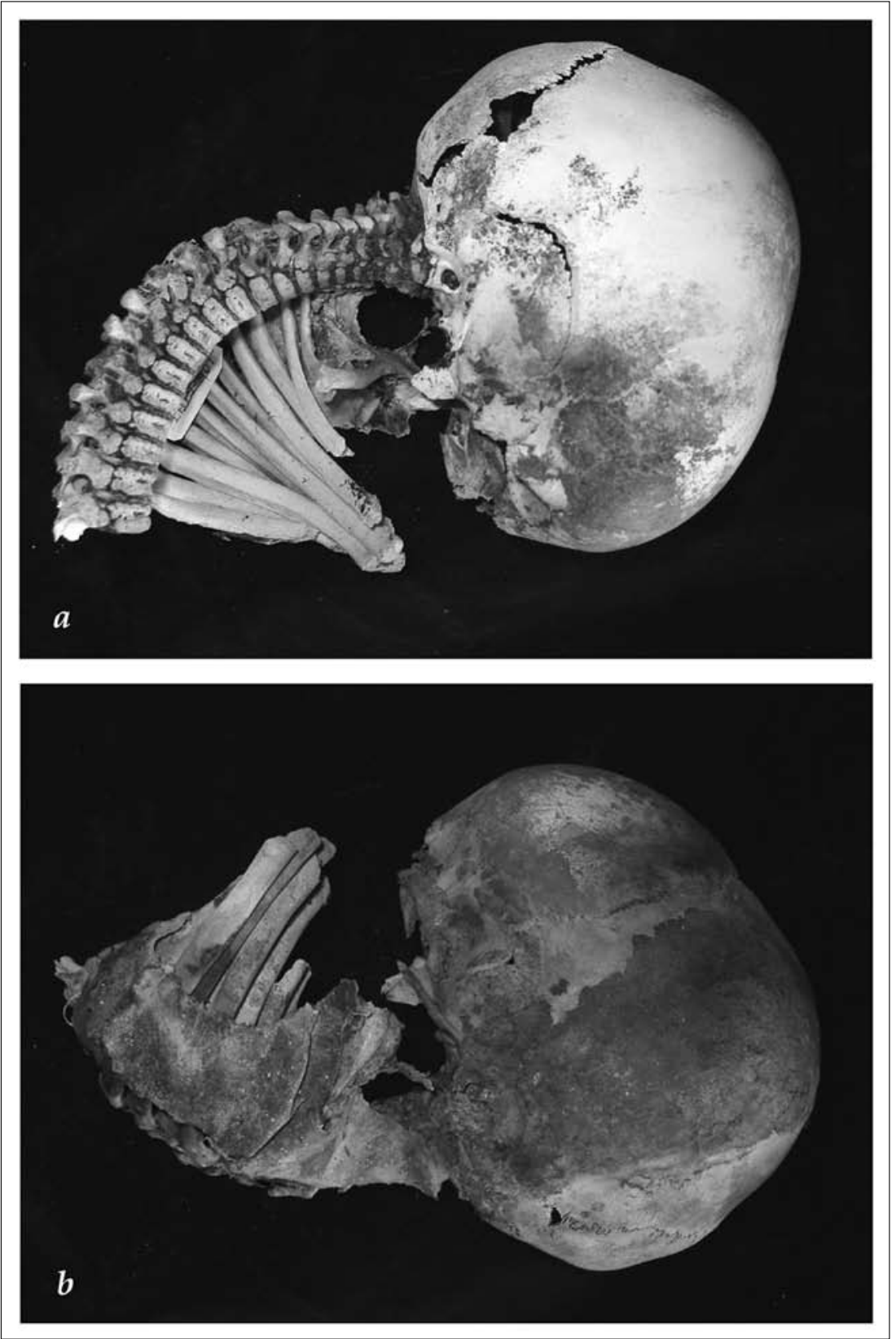

Figure 7. (a) Right and (b) left sides of a primary interment of juvenile individual.

(a) Lado derecho y (b) lado izquierdo del enterramiento primario de un individuo juvenil.

introduced into the region by the Inca (Guillén 2003; von Hagen 2002; Wild et al. 2007). Radiocarbon dates of samples derived from the secondary skeletal bundles fall into the Late Intermediate Period (AD 1,000-1,470), while those derived from the mummified remains are solidly within the Late Horizon (AD 1,470-1,532) (Table 1 and Figure 8). It is important to note that we are not suggesting that the mummies from the Laguna de los Cóndores are not from the Late Horizon; we are simply arguing that they do not necessarily represent "Inca" mummies, or the introduction of a mummification tradition.

The presence of mummified remains at the Laguna Huayabamba and the radiocarbon dates derived from anthropogenic wood artifacts (Table 1 and Figure 8: Beta Beta-147871 and Beta-147872), 


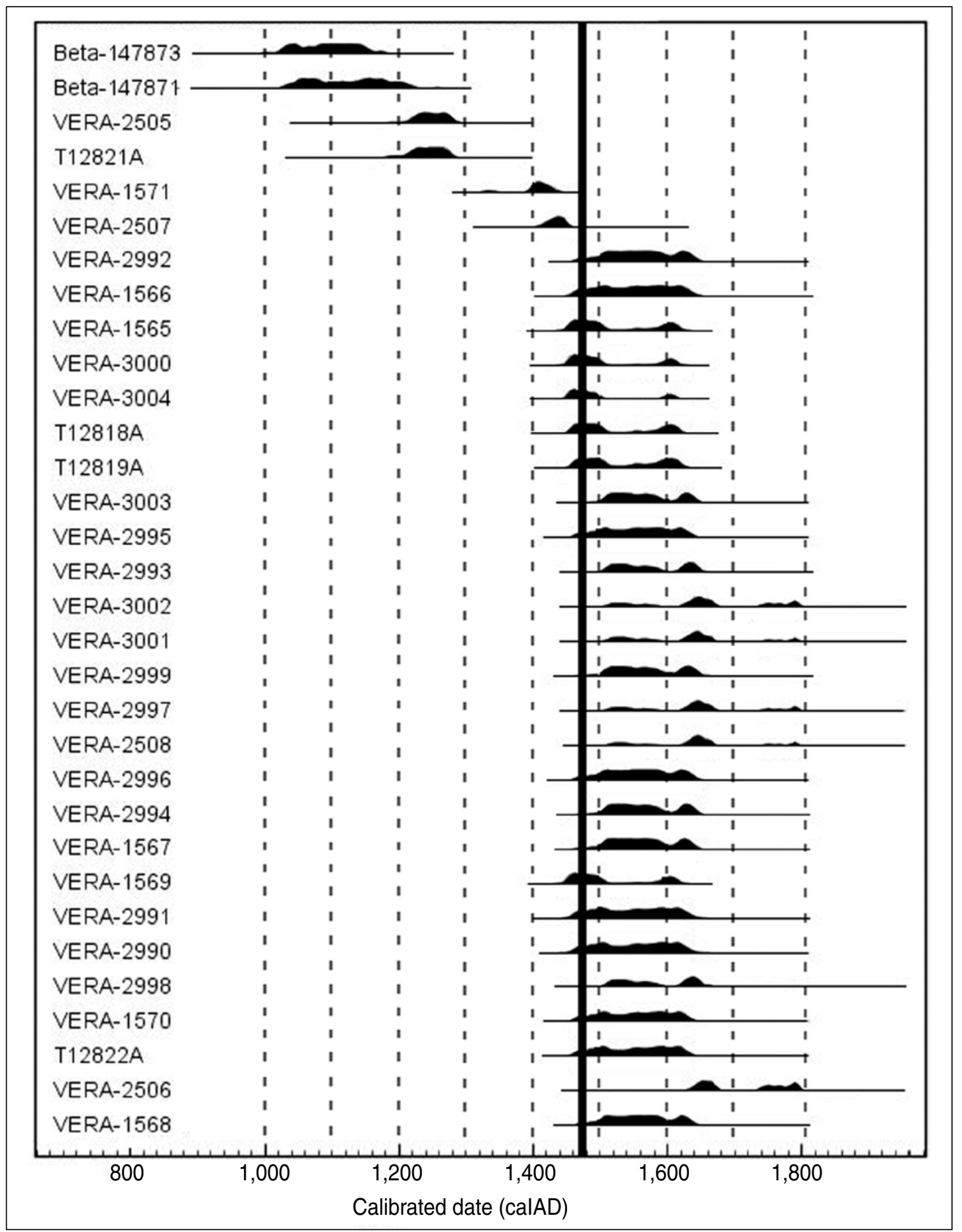

Figure 8. Probability distributions of calibrated radiocarbon dates from the Laguna Huayabamba, Laguna de los Cóndores, and Los Pinchudos. All calibrated dates were obtained using OxCal 4.0 (Bronk 1995, 2001, 2007) and the SHCal04 calibration curve (MacCormac et al. 2004). The solid black line represents the estimated time of Inca conquest and consolidation of Chachapoya (ca. AD 1470).

Distribución probabilística de datos radiocarbónicos calibrados de Laguna Huayabamba, Laguna de los Cóndores y Los Pinchudos. Todas las calibraciones se obtuvieron a través de OxCal 4.0 (Bronk 1995, 2001, 2007) y la curva de calibración SHCal04 (MacCormac et al. 2004). 
corroborated by ceramic evidence, would indicate that mummification existed in the Chachapoya region prior to the arrival of the Inca. Strictly speaking the remains from the Laguna Huayabamba are not, based upon the available evidence, anthropogenic. Nonetheless, as indicated in the treatment of Fardo 4 and 9, they were subjected to an elaborate post-mortem process.

Clearly, the recovery of imperial material culture from sites like Los Pinchudos (Morales et al. 2002) and the Laguna de los Cóndores (Guillén 2003), including ceramics and textiles, indicates that the conquest did influence Chachapoya mortuary behavior. The use of such markers of imperial power by the Chachapoya suggests that they were utilizing and adapting to the new political structure, incorporating it into their sociopolitical and ideological lives. As presented in this paper, however, mummification already existed in the Chachapoya region prior to conquest. Evaluation of other pre-Inca Chachapoya mummies will need to be conducted in order to determine exactly how they were produced prior to Inca arrival.

Lastly, we move to consider the observable range of Chachapoya mortuary behavior. Though temporal control is limited, there is evidence of burial within caves, anthropomorphic sarcophagi, and chullpas. Body processing seems to include the secondary interment of skeletal material and some form of mummification. Though devoid of temporal context, and therefore of limited interpretive value, there are other examples of Chachapoya mummies that were not eviscerated. There are eight mummies housed at the Museo del Instituto de Nacional in the modern town of Chachapoyas. All of these mummies were unwrapped and many of them were remarkably intact, thus it was possible to visualize the perineal region on five of the mummies. Out of these five mummies, four were not eviscerated through the anus or vagina, which has been suggested to be the method employed on the mummies from the Laguna de los Cóndores (Guillén 1998; Wild et al. 2007). While this evidence cannot be used to conclude one way or the other if mummification existed in the Chachapoya region prior to Inca arrival, they do indicate that there was quite a bit of diversity in Chachapoya mortuary behavior.

Rather than considering the available radiocarbon data as evidence for the introduction of a new behavior (eg. anthropogenic mummification), the same data can be used to support the existence of a unified ritual landscape in which continued access to the ancestors resulted in their gradual transformation from fleshed mummies to dry bones. The radiocarbon dates produced by Wild et al. (2007) indicate a temporal sequence, with older secondarily manipulated skeletal remains and more recent mummy bundles. The consideration of two facts, however, allows us to propose a slightly different scenario.

First, the presence of Chachapoya mummies at the Laguna Huayabamba indicates that this form of mortuary tradition was not introduced by the Inca. Therefore, the presence of these two body processing techniques (i.e., mummification and skeletal remains) indicates that any transformation of mortuary behavior was autochthonous in origin. Secondly, continued access to the ancestors appears to be a common theme in Chachapoya mortuary behavior (Guillén 2003; Nystrom 2005; Urton 2001). At the most basic level, the chullpas contain several generations of ancestors, clear evidence that these sites continued to maintain their place within the society of the living. Based upon the presence of 32 khipus at the Laguna de los Cóndores site, Urton (2001) proposes that there was a significant degree of interaction between the living and the ancestors. Guillén (2003:163) also suggests that the mummy wrappings were changed or added through time. Given these factors, what we interpret in the archaeological record as distinct mortuary practices could be the result of an extended transformation process in which fleshed remains transition into skeletal remains (Brown 1981). As new mummy bundles were placed within the chullpas, the old mummy bundles may have been moved, manipulated, or even re-wrapped (Guillén 2003:163). The funerary bundles consisting of the skeletal remains of multiple individuals could result from this process of continued interaction and manipulation of the ancestors. And despite a gross visual distinction, one that is emphasized by our methodological biases, as examples of secondary mortuary rituals, both mummification and secondarily interred dry bones emphasize and strengthen the identity of the group, cross-cutting household or family lines, bringing the populace together in which common symbols reinforce group identity over personal identity (Kuijt 2000).

While this paper is necessarily preliminary in nature, it touches on several important issues. First, and most broadly, it questions the emphasis on methodological distinctions in the description 
of mummification processes. Being bound by a methodological bias may potentially influence our understanding of meaning. This paper also addresses issues related to Inca imperialism and more specifically, its impact on Chachapoya mortuary behavior. While additional data will need to be collected, provisionally it appears that the range of mortuary behavior observed in the region is due to an extended tradition based on continued access and interaction with the ancestors on the part of the living.

Acknowledgments: Funding was provided to the primary author from the National Science
Foundation, Latin American and Iberian Institute and the Student Resource Allocation Committee at the University of New Mexico. Warren B. Church supplied some of the radiocarbon dates reported in Table 1. This study would not have been possible without the assistance of Claudia Grimaldo, Jesus Briceño, and the community of Uchucmarca where the Laguna Huayabamba material is stored. The first author would like to thank Marla Toyne for assisting in the Spanish translation of the abstract. Finally, the authors would like to thank the anonymous reviewers and the editors of Chungara for their thoughtful advice.

\section{References Cited}

Alconini, S.

2004 The Southeastern Inka frontier against the Chiriguanos: Structure and dynamics of the Inka Imperial borderlands. Latin American Antiquity 15:389-418.

Aldenderfer, $M$.

1993 Ritual, hierarchy, and change in foraging societies. Journal of Anthropological Archaeology 12:1-40.

Aufderheide, A.C.

2003 The Scientific Study of Mummies. Cambridge University Press, Cambridge.

Allen, C.J.

2002 The Hold Life Has: Coca and Cultural Identity in an Andean Community, $2^{\text {nd }}$ Edition. Smithsonian Books, Washington.

Allison, M.J., A. Pezzia, E. Gerszten, and D. Mendoza

1974 A case of Carrion's disease associated with human sacrifice from the Huari Culture of Southern Peru. American Journal of Physical Anthropology 41:295-300.

Arriaza, B.T.

1995a Beyond Death: The Chinchorro Mummies of Ancient Chile. Smithsonian Institution Press, Washington.

1995b Chinchorro bioarchaeology: Chronology and mummy seriation. Latin American Antiquity 6:35-55.

Bastien, J.W.

1978 Mountain of the Condor: Metaphor and Ritual in an Andean Ayllu. Waveland Press, Inc., Prospect Heights, Illinois.

1995 The Mountain/Body metaphor expressed in a Kaatan funeral. In Tombs for the Living: Andean Mortuary Practices, edited by T.D. Dillehay, pp. 355-378. Dumbarton Oaks Research Library and Collection, Washington, D.C.

Bauer, B. S.

1992 The Development of the Inca State. University of Texas Press, Austin.

Bittmann, B., and J. Munizaga

1976 The earliest artificial mummification in the world? A study of the Chinchorro Complex in Northern Chile. Folk 18:61-92.

Bloch, M., and J. Parry

1982 Introduction: death and the regeneration of life. In Death and the Regeneration of Life, edited by M. Bloch and J. Parry, pp. 1-44. Cambridge University Press, Cambridge.

Bracamonte Ganoza, F.

2002 Los Pinchudos: un estudio preliminar de su población. Sian 8(12):14-15.

Bray, T.L.

1992 Archaeological survey in Northern highland Ecuador: Inca imperialism and the País Caranqui. World Archaeology 24:218-233.

Briceño, J., and K. Muscutt

2004 Fardos funerarios Chachapoya en la Laguna Huayabamba. Sian 9(15):6-7.

Bronk Ramsey, C.

1995 Radiocarbon calibration and analysis of stratigraphy: The OxCal program. Radiocarbon 37(2):425-430.

2001 Development of the radiocarbon calibration program OxCal. Radiocarbon 43(2A):355-363

2007 Deposition Models for Chronological Records. Quaternary Science Reviews 27:42-60.

Brown, J.A.

1981 The search for rank in prehistoric burials. In The Archaeology of Death, edited by R. Chapman, I. Kinnes, and K. Randsborg, pp. 25-37. Cambridge University Press, Cambridge.

Buikstra, J.E.

1995 Tombs for the living...or...for the dead: The Osmore ancestors. In Tombs for the Living: Andean Mortuary Practices, edited by T. D. Dillehay, pp. 229-280. Dumbarton Oaks Research Library and Collection, Washington, D.C.

Buikstra, J.E., and K.C. Nystrom

2003 Embodied traditions: The Chachapoya and Inca ancestors. In Theory, Method, and Practice in Modern Archaeology, edited by R.J. Jeske and D.K. Charles, pp. 29-48. Praeger Publishers, Westport, Connecticut.

Buikstra J.E. and D.E. Ubelaker 1994 Standards for Data Collection from Human Skeletal Remains: Proceedings of a Seminar at the Field Museum of Natural History. Arkansas Archaeological Survey Research Series No. 44 Fayetteville, Arkansas. 
Chesson, M.S.

2001 Embodied memories of place and people: Death and society in an Early urban community. In Social Memory, Identity and Death: Anthropological Perspectives on Mortuary Rituals, edited by M.S. Chesson, pp. 100-113. Archaeological Papers of the American Anthropological Association Number 10, Arlington, Virginia.

Church, W.B.

1997 Más allá del Gran Pajatén: conservando el paisaje prehispánico Pataz-Abiseo. Revista del Museo de Arqueología, Antropología e Historia 7:205-248. Facultad de Ciencias Sociales de la Universidad Nacional de Trujillo. Trujillo, Perú.

Costin, C., T. Earle, B. Owen, and G. Russell

1989 The impact of Inca conquest on local technology in the Upper Mantaro Valley, Peru. In What's New: A Closer Look at the Process of Innovation, edited by S.E. van der Leeuw, and R. Torrence, pp. 107-139. Unwin Hyman, London.

Covey, R.A.

2000 Inka administration of the far South Coast of Peru. Latin American Antiquity 11:119-138.

D'Altroy, T.N.

2003 The Incas. Blackwell Publishers, Oxford.

2005 Remaking the social landscape: Colonization in the Inca Empire. In The Archaeology of Colonial Encounters: Comparative Perspectives, edited by G.J. Stein GJ, pp. 263295. School of American Research Press, Santa Fe, NM.

D'Altroy, T.N. and R.L. Bishop

1990 The Provincial Organization of Inka Ceramic Production. American Antiquity 55:120-138.

D'Altroy, T.N., A.M. Lorandi, V.I. Williams, C.A. Hastorf, E. DeMarrais, M. Calderari, and M.B. Hagstrum

2000 Inka rule in the Northern Calchaquí Valley, Argentina. Journal of Field Archaeology 27:1-26.

DeLeonardis, L. and G.F. Lau

2004 Life, death, and ancestors. In Andean Archaeology, edited by H. Silverman, pp. 77-115. Blackwell Publishing, Malden.

Dillehay, T.D.

1995 Introduction. In Tombs for the Living: Andean Mortuary Practices, edited by T.D. Dillehay, p. 1-26. Dumbarton Oaks Research Library and Collection, Washington, D.C.

Espinoza, S.W.

1967 Los señoríos étnicos de Chachapoyas y la alianza hispano-chacha: Visitas, informaciones y memoriales inéditos de 1572-1574. Revista Histórica (Lima) 30:224-283.

Fernández-Dávila, D.

2008 Architecture and Landscape in Vira Vira: Marking Dualisms on an Andean Ridge. Unpublished MA thesis, University of Leicester, England.

Gil, N.

1936 Las tumbas esculturales de Aispachaka. Boletín de la Sociedad Geográfica de Lima 53:235-239.

Gose, P.

1994 Deathly Waters and Hungry Mountains: Agrarian Ritual and Class Formation in an Andean Town. University of Toronto Press, Toronto.

Guillén, S.E.

1992 The Chinchorro Culture: Mummies and Crania in the Reconstruction of Preceramic Coastal Adaptation in the South Central Andes. PhD dissertation, University of Michigan, Michigan.

1998 Laguna de los Cóndores: Donde viven los muertos. Bien Venida 6:43-48.

2003 Keeping ancestors alive: The mummies from Laguna de los Cóndores, Amazonas, Perú. In Proceedings of the 4th World Congress on Mummy Studies. Nuuk, Greenland, September 4-10, 2001, edited by N. Lynnerup, C. Andreasen and J. Berglund, pp. 162-164. Greenland National Museum and Archives and Danish Polar Center, Copenhagen.

2005 Mummies, cults, and ancestors: the Chinchorro mummies of the South Central Andes. In Interacting with the Dead: Perspectives on Mortuary Archaeology for the New Millenium, edited by G.F.M. Rakita, J.E. Buikstra, L.A. Beck, and S.R. Williams, pp. 142-149. University Press Florida, Gainsville.

Hastorf, C.A.

1990 The effect of the Inka State on Sausa agricultural production and crop consumption. American Antiquity 55:262-290.

Hertz, R.

1960 [1907] Death and the Right Hand. Edited and translated by R. Needham and C. Needham. The Free Press, Glencoe.

Joyce, R.A.

2001 Burying the dead at Tlatilco: Social memory and social identities. In Social Memory, Identity and Death: Anthropological Perspectives on Mortuary Rituals, edited by M.S. Chesson, pp. 12-26. Archaeological Papers of the American Anthropological Association, Monograph 10. Arlington.

Kauffmann, D.F.

1997 Los mausoleos de la Laguna de las Momias Arkinka 24:94-112.

2002 Historia y Arte del Perú Antiguo Vol 4. Lima.

Kauffmann D.F., M. Salazar, D. Morales, I. Mackay, and O. Sacay

1989 Andes amazónicos: Sitios intervenidos por la Expedición Antisuyo/86. Arqueológicas 20. Museo Nacional de Antropología y Arqueología, Lima.

Kuijt, I.

2000 Keeping the peace: Ritual, skull caching, and community integration in the Levantine Neolithic. In Life in Neolithic Farming Communities: Social Organization, Identity, and Differentiation, edited by I. Kuijt, pp. 137-162. Kluwer Academic/Plenum Publishers, New York.

Langlois L.

1934 Las ruinas de Cuelap. Boletín de la Sociedad Geográfica de Lima 51:20-34.

1940 Utcubamba: Investigaciones arqueológicas en este valle del Departmento de Amazonas (Perú) Continuación. Revista del Museo Nacional. 9(1):33-72.

Lee, V.R.

1994 The ruins of Vira Vira. South American Explorer 39:1419.

LeVine, T.Y.

1987 Inka labor service at the regional level: The functional reality. Ethnohistory 34(1):15-46.

McCormac, F.G., A.G. Hogg, P.G. Blackwell, C.E. Buck, T.F.G. Higham, and P.J. Reimer 
2004 SHCal04 Southern Hemisphere calibration, 0-11.0 cal kyr BP. Radiocarbon 46(3):1087-1092.

Meskell, L.M.

2000 Writing the body in archaeology. In Reading the Body, edited by A.E. Rautman, pp. 12-31. University of Pennsylvania Press, Philadelphia.

Morales Gamarra, R.

2002 Los Pinchudos, arquitectura funeraria en Río Abiseo, San Martín. Parte I. Arkinka 76:92-101.

Morales Gamarra, R., L.V. Álvarez, W.B. Church, and L.C. Tello

2002 Los Pinchudos: Un estudio preliminar de su población. Sian 8(12):1-41.

Morris, C., and R.A. Covey

2006 The management of scale or the creation of scale: Administrative processes in two Inka Provinces. In Intermediate Elites in Pre-Columbian States and Empires, edited by C.M. Elson and R.A. Covey, pp. 136-153. University of Arizona Press, Tucson.

Moseley, M.E.

1992 The Incas and Their Ancestors. Thames and Hudson, London.

Muscutt, K.

2003 Unpublished History Channel Site Report on Vira Vira, Perú. Manuscript in possession of authors.

Muscutt, K., V.R. Lee, and D. Sharon

1994 Vira Vira: A "new” Chachapoya site. South American Explorer 39:5-30.

Murra, J.V.

1982 The mit'a obligations of ethnic groups to the Inka State. In The Inca and Aztec States 1400-1800: Anthropology and History, edited by G.A. Collier, R.I. Rosaldo, and J.D. Wirth, pp. 237-262. Academic Press, New York.

Narváez Vargas, L.A.

1996a La Fortaleza de Kuélap. Arkinka 12:92-108.

1996b La Fortaleza de Kuélap. Arkinka 13:90-98.

Nystrom, K.C.

2005 The Biological and Social Consequences of Inca Conquest of the Chachapoya region of Northern Perú. $\mathrm{PhD}$ dissertation, University of New Mexico, Albuquerque.

Nystrom, K.C., A. Goff, and M.L. Goff

2005 Mortuary behavior reconstruction through paleoentomology: A case study from Chachapoya, Perú. International Journal of Osteoarchaeology 15(3):175-185.

Rivera, M.A.

1995 The Preceramic Chinchorro mummy complex of Northern Chile: Context, style, and purpose. In Tombs for the Living: Andean Mortuary Practices, edited by T.D. Dillehay, pp. 43-78. Dumbarton Oaks Research Library and Collection, Washington, D.C.

Salomon, F.

1995 "The beautiful grandparents": Andean ancestor Shrines and mortuary ritual as seen through Colonial records. In
Tombs for the Living: Andean Mortuary Practices, edited by T.D. Dillehay, p. 315-353. Dumbarton Oaks Research Library and Collection, Washington, D.C.

Schjellerup, I.

1997 Incas and Spaniards in the Conquest of the Chachapoya, Archaeological and Ethnohistorical Research in the Northeastern Andes of Perú. GOTARC, series B, Gothenburg Archaeological Theses, 7. Göteborg University.

Sharon, D.

1994 Vira Vira in Andean context. South American Explorer 39:20-30.

Sillar, B.

1996 The dead and the dying: Techniques for transforming people and things in the Andes. Journal of Material Culture 1:259-289.

Terada, K., and R. Matsumoto

1985 Sobre la cronología de la tradición Cajamarca. In Historia de Cajamarca. I. Arqueología, edited by F.S. Santisteban, W.E. Soriano, and R. Ravines, pp. 67-90. Instituto Nacional de Cultura, Corporación de Desarrollo de Cajamarca, Cajamarca.

Urton, G.

2001 A calendrical and demographic tomb text from Northern Perú. Latin American Antiquity 12:127-148.

Verdery, K.

1999 The Political Lives of Dead Bodies: Reburial and Postsocialist Change. Columbia University Press, New York.

van Gennep, A.

[1909] 1960 The Rites of Passage. Translate by M.B. Vizedom and G.L. Cafee. University of Chicago Press, Chicago.

von Hagen, A.

2002 Chachapoya iconography and society at Laguna de los Cóndores, Perú. In Andean Archaeology Volume II: Art, Landscape, and Society, edited by H. Silverman and W.H. Isbell, pp. 137-155. Kluwer Academic/Plenum Publishers, New York.

Vreeland, J.M.

1998 Mummies of Peru. In Mummies, Disease, and Ancient Cultures. 2nd Edition, edited by A. Cockburn, E. Cockburn, and T. A. Reyman, pp. 154-189. Cambridge University Press, Cambridge.

Wernke, S.A.

2006 The politics of community and Inka statecraft in the Colca Valley, Peru. Latin American Antiquity 17:177208.

Wild, E.M., S. Guillén, W. Kutschera, H. Seidler, and P. Steier

2007 Radiocarbon dating of the Peruvian Chachapoya/Inca site at the Laguna de los Cóndores. Nuclear Instruments and Methods in Physics Research B 259:378-383. 


\section{Notes}

1 Chachapoya is the term commonly utilized to refer to the prehistoric inhabitants and region, whereas Chachapoyas is the term used to refer to the modern day city and political department.

2 The author indicates that radiocarbon dating was done at the Universita degli Studi di Roma/Centro Interdisplinare per la Datazioni con il Metodo del Carbono 14, but does not provide the original uncalibrated date nor which calibration curve was used.

3 Encontré en ese orificio cinco cráneos y osamentas, que no correspondían sino a un cuerpo o, cuando más a dos. Se habían, por consiguiente, encerrado tres cráneos sin cuerpos (Langlois 1934:30).

4 ¿Qué debemos pensar de este curioso procedimiento? Tal vez, estas osamentas hayan sido traídas de lugares muy lejanos y una parte se haya perdido en el trajecto. ¿O bien se trata de la tumba de un guerrero, enterrado con sus trofeos de guerra (Langlois 1934:30)?

5 “....el cadáver era momificado y envuelto en tejidos. Se le daba posición fetal o de cuclillas y se le sentaba encima de un pellejo que cubría a la redonda el sector inferior de la momia" (Kauffmann et al. 1989:24).

6 Warren Church provided the uncalibrated BP dates for Los Pinchudos. These were calibrated using $\mathrm{OxCal} 4.0$ and the ShCal04 calibration curve for this paper.

7 In the original Wild et al (2007) article, the authors used OxCal 3.10 and the IntCal04 calibration curve.

8 See footnote 7. 
